\title{
Effects of dietary supplementation with breadfruit leaf powder on growth performance, meat quality, and antioxidative activity in Japanese quail
}

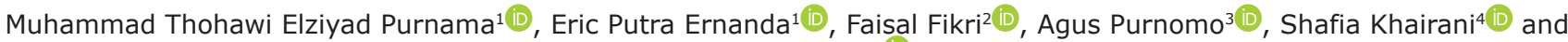 \\ Shekhar Chhetri ${ }^{5}$ i⿺
}

1. Division of Veterinary Anatomy, Department of Veterinary Science, Faculty of Veterinary Medicine, Universitas Airlangga, Surabaya, Indonesia; 2. Division of Veterinary Clinical Pathology and Physiology, Department of Veterinary Science, Faculty of Veterinary Medicine, Universitas Airlangga, Surabaya, Indonesia; 3. Department of Veterinary Surgery and Radiology, Faculty of Veterinary Medicine, Universitas Gadjah Mada, Yogyakarta, Indonesia; 4. Department of Biomedical Science, Faculty of Medicine, Universitas Padjajaran, Bandung, Indonesia; 5. Department of Animal Science, College of Natural Resources, Royal University of Bhutan, Lobesa, Punakha, Bhutan.

Corresponding author: Muhammad Thohawi Elziyad Purnama, e-mail: thohawi@fkh.unair.ac.id

Co-authors: EPE: eric.putra.ernanda-2015@fkh.unair.ac.id, FF: faisalfikri@fkh.unair.ac.id, AP: agus.fkh@ugm.ac.id, SK: shafia@unpad.ac.id, SC: shekhar.cnr@rub.edu.bt

Received: 16-03-2021, Accepted: 15-06-2021, Published online: 28-07-2021

doi: www.doi.org/10.14202/vetworld.2021.1946-1953 How to cite this article: Purnama MTE, Ernanda EP, Fikri F, Purnomo A, Khairani S, Chhetri S (2021) Effects of dietary supplementation with breadfruit leaf powder on growth performance, meat quality, and antioxidative activity in Japanese quail, Veterinary World, 14(7): 1946-1953.

\begin{abstract}
Background and Aim: In an era of increasing concerns about food availability globally, poultry meat is being increasingly consumed rather than red meat given its quality in terms of $\mathrm{pH}$, color, and tenderness, conferring consumer satisfaction. The choice of feed is a crucial factor in poultry production. This study investigated the effect of dietary supplementation with breadfruit leaf powder on growth performance, meat quality, and antioxidative activity in Japanese quail.

Materials and Methods: A total of 120 day-old quail were used in this study and assigned equally into four treatment groups: Group C fed a basal diet and three treatment groups fed a basal diet supplemented with $2.5 \%$ (T1), $5 \%$ (T2), or $10 \%$ (T3) breadfruit leaf powder. The concentrations of breadfruit leaf powder were $2.5,5$, and $10 \mathrm{~g} / \mathrm{kg}$ in the basal diet. Quail body weight and feed intake (FI) were evaluated at 1,21, and 35 days of age at 7 a.m. Pectoral muscle was collected to determine $\mathrm{pH}$, meat color, drip loss, cooking loss, water-holding capacity (WHC), tenderness, and antioxidant levels. All variables were analyzed statistically using ANOVA followed by Duncan's post hoc test (significance set at $\mathrm{p}<0.05$ ).
\end{abstract}

Results: T3 showed increased body weight gain of quails at $1-21$ and $21-35$ days $(\mathrm{p}<0.05)$. Feeding in the T3 group improved the feed conversion ratio compared with those in the $\mathrm{C}$ and $\mathrm{T} 1$ groups at the starter phase $(\mathrm{p}<0.05)$. Dietary treatment did not affect FI $(\mathrm{p}>0.05)$. In the present study, meat redness and WHC were improved in the T3 group $(\mathrm{p}<0.05)$. Meanwhile, drip loss, cooking loss, and meat tenderness were improved in the $\mathrm{T} 2$ group $(\mathrm{p}<0.05)$. $\mathrm{The} \mathrm{pH}_{45 \text { min }}, \mathrm{pH}_{24}$, lightness, and yellowness were not influenced by the treatments $(p>0.05)$. The antioxidative activities of superoxide dismutase and malondialdehyde decreased in the T3 group $(\mathrm{p}<0.05)$, while no significant difference in glutathione peroxidase level $(\mathrm{p}>0.05)$ was identified.

Conclusion: Ten grams/kilogram of breadfruit leaf powder, as administered in the T3 group, can be applied as a dietary supplement for Japanese quail to improve growth performance, meat quality, and antioxidative activity during the starter and grower periods.

Keywords: antioxidative activity, breadfruit leaf powder, food availability, growth performance, Japanese quail, meat quality.

\section{Introduction}

In recent years, the consumption of poultry meat in Indonesia has increased. The popularity of poultry on the market has also shown a tendency to increase compared with that of beef [1]. Japanese quail (Coturnix coturnix japonica) is a poultry commodity that is popular with consumers. Quail is

Copyright: Purnama, et al. Open Access. This article is distributed under the terms of the Creative Commons Attribution 4.0 International License (http://creativecommons.org/licenses/ by/4.0/), which permits unrestricted use, distribution, and reproduction in any medium, provided you give appropriate credit to the original author(s) and the source, provide a link to the Creative Commons license, and indicate if changes were made. The Creative Commons Public Domain Dedication waiver (http:// creativecommons.org/publicdomain/zero/1.0/) applies to the data made available in this article, unless otherwise stated. used for two purposes: To produce eggs and meat [2]. Several studies have been conducted to determine the health benefits of quail meat and its meat quality compared with those of other poultry [3]. Quail rapidly reaches sexual maturity, resistance to environmental temperature and starting to adapt to maintaining body weight t 3-5 weeks of age. Male quail can be harvested at 5-6 weeks of age with a body weight of 100-140 $\mathrm{g}$ and acarcass percentage of $73.33 \%$ [4]. Moreover, in production, adult quail can be harvested at 6-7 weeks with a weight of $300 \mathrm{~g}$ and a carcass range of $75-78 \%$ [5].

Consumer satisfaction is often achieved if meat has a soft texture [6]. The main components of meat that play an important role in the level of tenderness 
are connective tissue, muscle fibers, and fat tissue [7]. Less connective tissue in meat confers a soft texture on it. With higher levels of marbling fat or intramuscular fat, the texture of meat becomes more tender. The presence of intramuscular fat in muscle loosens the muscle fiber bonds, thus providing opportunities for meat protein to bind water [8].

Factors that can affect the water-binding capacity (water-holding capacity [WHC]) are $\mathrm{pH}$, muscle type and location, muscle function, age, feed, rigor mortis phase, and intramuscular fat level and species [9]. The WHC increases in direct proportion to the $\mathrm{pH}$ of meat. A low $\mathrm{pH}$ of meat can decrease its WHC [10]. pH levels, length of muscle sarcomeres, pieces of muscle fibers, myofibril contraction, and size and weight of meat samples affect the cooking losses, which are in the range of about $1.5-54.5 \%$. Quail meat has a dark color since the ratio of dark to light muscles in quail breast meat is $95.1-96.7 \%: 3.7-4.9 \%$. This predominance of dark meat in quail confers a tougher texture, as dark meat is tougher than light meat [11]. There is thus a need to formulate an additional feed to tenderize quail meat.

Breadfruit (Artocarpus altilis) is a versatile plant because all parts of itcan be used for medicinal plants. The leaves of breadfruit contain various natural antioxidants, such as flavonoids, carotenoids, hydrocyanic acid, acetylcholine, tannins, riboflavins, saponins, phenols, quercetin, kaempferol, potassium, and Vitamins A, E, and C [12]. The antioxidant status of feed is associated with meat quality [13]. The aforementioned components of breadfruit leaves are expected to improve meat quality and tenderness through antioxidant activity in quail meat. The previous studies on breadfruit leaves proved that they can be used as a fattening formula [14].

This study aimed to evaluate the effects of dietary supplementation with breadfruit leaf powder on the growth performance, meat quality, and antioxidative activity in Japanese quail.

\section{Materials and Methods}

Ethical approval

This study was approved by Ethical Committee of Animal Care and Use No.768/HRECC.FODM/ XII/2019 Universitas Airlangga. Experimental animals were healthy male sexed day-old quail (DOQ) purchased from private breeding farm.

\section{Study period and location}

This study was conducted for 2 months (September and October 2019). The DOQ was reared in a private breeding farm. Proximate analysis was evaluated at laboratory animal nutrition, Faculty of Veterinary Medicine, Universitas Airlangga. Meat examinations were performed at the Laboratory of Animal Production, PSDKU Banyuwangi, Universitas Airlangga. The antioxidative parameter was evaluated at Gamma Scientific Biolab, Malang, East Java.

\section{Experimental design}

A total of 120 DOQ were reared and equally assigned into four treatment groups. The control (C) group was fed with a basal diet, while the treatment groups were fed a basal diet supplemented with $2.5 \%$ (T1), $5 \%$ (T2), or $10 \%$ breadfruit leaf powder (T3). The concentrations of breadfruit leaf powder were 2.5, 5, and $10 \mathrm{~g} / \mathrm{kg}$ in the basal diet. The basal diet components and nutrient contents are shown in Table-1. The treatments were applied in the starter phase (1-21 days) and grower phase (21-35 days).

Quail body weight and feed intake (FI) were evaluated per replicate on 1, 21, and 35 days of age at 7 a.m. The growth performance represented as FI, body weight gain (BWG), and feed conversion ratio (FCR) was evaluated in the starter phase (1-21 days), grower phase (21-35 days), and the whole period (1-35 days). Quails were not vaccinated during treatment. At the end of the study, quails were slaughtered and the pectoral muscle was collected in plastic bags for evaluation.

\section{Proximate analysis of breadfruit leaf powder}

The breadfruit leaves (Herb No.074/338A) used in this study were identified from Glagah, Banyuwangi (810’31.1”S $\left.114^{\circ} 17^{\prime} 07.5^{\prime \prime} \mathrm{E}\right)$ by Mr. Husin, a botanist. The leaves were collected and then chopped, dried, and mashed into powder. The proximate analysis was performed in accordance with the AOAC method [15]. The carbohydrate content was determined by the formula [carbohydrate $=$ feed mass $-($ ash + crude protein + fat + fiber)]. The ash content was evaluated using a muffle electric furnace by ashing the samples overnight at $600^{\circ} \mathrm{C}$. The crude protein analysis was performed using the Kjeldahl method. The total fat analysis was performed using the soxhletation method. The results of proximate analysis of the experimental diets are shown in Table-2.

\section{Meat quality determination}

The initial pH (at $45 \mathrm{~min}$ ) and the final pH (24 h) after slaughter were recorded using a digital $\mathrm{pH}$ meter (EcoTestr, USA) with an accuracy of \pm 0.1 [16]. Meat color was determined using a chromatometer color reader (Konica Minolta, Japan) for the variables of $\mathrm{L}^{*}$ (lightness), $\mathrm{a}^{*}$ (redness), and $\mathrm{b}^{*}$ (yellowness), according to the Commission Internationale de L'Eclairage (CIE) lab color system, on the posterior surface of the pectoral muscle. Color was measuredat three different sites [17].

Drip loss was analyzed by determining the initial weight (x) of the meat sample, which was then wrapped in a plastic bag and stored in a refrigerator for $24 \mathrm{~h}$. The sample was weighed again to determine the final weight (y) by wiping with a tissue without pressing [18]. Drip loss was calculated using the following equation:

$$
\text { Driploss }=\frac{x-y}{x} \times 100 \%
$$

Frozen meat samples from the freezer were thawed at $4^{\circ} \mathrm{C}$ for $24 \mathrm{~h}$ and the initial weight (x) was 
Table-1: Feed ingredients and nutrients content of basal diets.

\begin{tabular}{|c|c|c|c|c|c|}
\hline \multirow[t]{2}{*}{ Ingredients $(\mathbf{g} / \mathbf{k g})$} & \multicolumn{2}{|c|}{ Diets } & \multirow[t]{2}{*}{ Nutrients } & \multicolumn{2}{|c|}{ Diets } \\
\hline & $\begin{array}{c}\text { Starter phase } \\
\text { (1-21 days) }\end{array}$ & $\begin{array}{l}\text { Grower phase } \\
\text { ( } 21-35 \text { days) }\end{array}$ & & $\begin{array}{c}\text { Starter phase } \\
\text { (1-21 days) }\end{array}$ & $\begin{array}{l}\text { Grower phase } \\
\text { (21-35 days) }\end{array}$ \\
\hline Corn & 530 & 589 & Metabolite energy $(\mathrm{MJ} / \mathrm{kg})$ & 12.98 & 12.98 \\
\hline Soybean meal & 336 & 322 & Crude protein $(\mathrm{g} / \mathrm{kg})$ & 227 & 206 \\
\hline Corn oil & 60 & 50 & Calcium $(\mathrm{g} / \mathrm{kg})$ & 10 & 9.1 \\
\hline Dicalcium phosphate & 16 & 16 & Phosphorus (g/kg) & 7.1 & 6.6 \\
\hline Calcium carbonate & 17 & 13 & Methionine and cystine & 9.0 & 6.3 \\
\hline Methionine & 2.0 & 1.0 & Lysine $(\mathrm{g} / \mathrm{kg})$ & 11.8 & 10 \\
\hline Vitamin premix & 25 & 25 & & & \\
\hline a. Vitamin A (IU) & 15000 & 15000 & & & \\
\hline b. Vitamin D3 (IU) & 3750 & 3750 & & & \\
\hline c. Vitamin E (mg) & 37.5 & 37.5 & & & \\
\hline d. Vitamin K3 (mg) & 2.55 & 2.55 & & & \\
\hline e. Thiamin (mg) & 3 & 3 & & & \\
\hline f. Riboflavin (mg) & 7.5 & 7.5 & & & \\
\hline g. Vitamin B6 (mg) & 4.5 & 4.5 & & & \\
\hline h. Vitamin B12 $(\mu \mathrm{g})$ & 24 & 24 & & & \\
\hline i. Niacin (mg) & 51 & 51 & & & \\
\hline j. Folic acid (mg) & 1.5 & 1.5 & & & \\
\hline k. Biotin (mg) & 0.2 & 0.2 & & & \\
\hline I. Pantothenic acid (mg) & 13.5 & 13.5 & & & \\
\hline m. Choline chloride $(\mathrm{mg})$ & 250 & 250 & & & \\
\hline n. Antioxidant (mg) & 100 & 100 & & & \\
\hline Mineral mix & 25 & 25 & & & \\
\hline a. Zinc (mg) & 37.5 & 37.5 & & & \\
\hline b. Manganese (mg) & 37.5 & 37.5 & & & \\
\hline c. Iron (mg) & 37.5 & 37.5 & & & \\
\hline d. Copper (mg) & 3.75 & 3.75 & & & \\
\hline e. Iodine (mg) & 0.83 & 0.83 & & & \\
\hline f. Sulfur & 62.5 & 62.5 & & & \\
\hline g. Selenium (mg) & 0.23 & 0.23 & & & \\
\hline Salt & 4.0 & 4.0 & & & \\
\hline
\end{tabular}

Table-2: Proximate analysis of the experimental diets.

\begin{tabular}{lcccccccc}
\hline Treatment & \multicolumn{7}{c}{ Contents (\%) } \\
\cline { 2 - 9 } & $\begin{array}{c}\text { Dry } \\
\text { matter }\end{array}$ & Ash & $\begin{array}{c}\text { Crude } \\
\text { protein }\end{array}$ & Fat & $\begin{array}{c}\text { Crude } \\
\text { fiber }\end{array}$ & Calcium & $\begin{array}{c}\text { Nitrogen-free } \\
\text { extract material }\end{array}$ & $\begin{array}{c}\text { Metabolic energy } \\
\text { (kcal/ kg) }\end{array}$ \\
\hline C & 90.03 & 5.77 & 20.27 & 5.25 & 4.21 & 2.23 & 54.52 & 3069.25 \\
T1 & 89.89 & 6.25 & 20.20 & 5.66 & 4.97 & 3.45 & 52.80 & 3035.18 \\
T2 & 89.92 & 6.60 & 18.99 & 5.95 & 6.91 & 3.49 & 51.48 & 2971.33 \\
T3 & 89.94 & 7.16 & 18.33 & 7.84 & 7.02 & 3.66 & 49.59 & 3016.14 \\
\hline
\end{tabular}

recorded. The meat sample was cooked in a water bath at $85^{\circ} \mathrm{C}$ for $10 \mathrm{~min}$ [19]. Subsequently, the weight (y) of the meat samples was again recorded to calculate the cooking loss using the following equation:

$$
\text { Cooking loss }=\frac{x-y}{x} \times 100 \%
$$

WHC was analyzed by homogenizing a $2 \mathrm{~g}$ sample of pectoral muscle with $4 \mathrm{~mL}$ of $0.6 \mathrm{M} \mathrm{NaCl}$ (x) in a tube. The homogenized samples were vortexed for $30 \mathrm{~s}$ and then incubated for $30 \mathrm{~min}$ at $4^{\circ} \mathrm{C}$. Thereafter, each sample was centrifuged (Hettich EBA 200, Germany) at $2889 \mathrm{rpm}$ for $30 \mathrm{~min}$ at $4^{\circ} \mathrm{C}$ [20]. The supernatant (y) was removed and WHC was calculated using the following equation:

$$
W H C=\frac{x-y}{x} \times 100 \%
$$

Tenderness was evaluated using a penetrometer. First, the sample was prepared by cutting the pectoral muscle to a size of $5^{\prime} 3^{\prime} 2 \mathrm{~cm}$. The penetrometer needle was calibrated to the meat surface and it was inserted into 10 different sites. The result of this was indicated by a number on the penetrometer scale. The maximum pressing duration required was $10 \mathrm{~s}$ [21].

\section{Antioxidant activity evaluation}

The samples were homogenized with a PRO 200 homogenizer (Pro Science, USA). Each homogenized sample was centrifuged at $10,000 \mathrm{rpm}$ for $20 \mathrm{~min}$ at $4^{\circ} \mathrm{C}$ to obtain supernatants followed by storage at $-20^{\circ} \mathrm{C}$ for subsequent analysis. The antioxidative activities of superoxide dismutase (SOD), malondialdehyde (MDA), and glutathione peroxidase (GPx) were determined using assay kits (Jiancheng Bioengineering Institute, China) [22].

\section{Statistical analysis}

All data were expressed as mean \pm standard error and analyzed using one-way analysis of variance followed by post hoc Duncan's comparison test. Values 
were considered significantly different at $\mathrm{p}<0.05$. Statistical analysis was performed using SPSS v.25 software (IBM, USA).

\section{Results}

\section{Growth performance}

Growth performance was observed using the variables FI, BWG, and FCR during the starter phase, grower phase, and the whole period. In general, FI was not influenced by the experimental diet. Supplementation of $10 \mathrm{~g} / \mathrm{kg}$ dietary breadfruit leaf powder (T3) caused an increase in BWG compared with that in the other treatment groups in all periods of treatment. Meanwhile, BWG in the T1 group showed no significant difference compared with that in the T2 and $\mathrm{T} 3$ groups at the grower phase (Table-3).

In addition, for FCR, the T3 group showed a significant difference compared with the $\mathrm{C}$ and $\mathrm{T} 1$ groups at the starter phase. From the grower phase and the whole period, no difference in FCR was observed. These results showed that supplementation of $10 \mathrm{~g} / \mathrm{kg}$ dietary breadfruit leaf powder improved BWG and FCR at the starter phase. In particular, this concentration increased BWG at the grower phase and the whole period (Table-3).

\section{Meat quality}

Meat quality was characterized using the following variables: $\mathrm{pH}_{45 \text { min }}, \mathrm{pH}_{24}$ he meat color (lightness, redness, and yellowness), drip loss, cooking loss, WHC, and tenderness. When compared with the $\mathrm{C}$ group, there were no significant differences in $\mathrm{pH}_{45 \text { min }}, \mathrm{pH}_{24}$ h lightness, and yellowness in all treatment groups. The T3 group presented significant differences compared with the other groups in terms of redness, drip loss, cooking loss, WHC, and tenderness. Meanwhile, the T2 and T3 groups showed similar observations regarding drip loss, cooking loss, and meat tenderness (Table-4). Based on the evaluation of meat quality traits, supplementation with $10 \mathrm{~g} / \mathrm{kg}$ dietary breadfruit leaf powder improved the quality of quail meat during the treatment period.

\section{Antioxidant activity}

In comparison to the findings in the other groups, the $\mathrm{T} 3$ group did not show a difference in GPx activity, but showed significant decreases in SOD and MDA activity. The results also showed a gradual improvement of SOD and MDA activity with progression of the experimental diet from T1 to T3 (Figure-1).

Table-3: Effects of experimental diets on growth performance in the end of treatment.

\begin{tabular}{lcccc}
\hline Variables & \multicolumn{3}{c}{ Treatment } \\
\cline { 2 - 5 } & $\mathbf{C}$ & $\mathbf{T 1}$ & $\mathbf{T 2}$ & T3 \\
\hline Feed intake (FI) (g) & & & & \\
$\quad$ Starter phase & $11.62 \pm 0.55$ & $10.72 \pm 0.54$ & $10.17 \pm 0.69$ & $10.79 \pm 0.35$ \\
$\quad$ Grower phase & $9.44 \pm 0.39$ & $8.29 \pm 0.99$ & $9.24 \pm 0.85$ & $10.65 \pm 0.49$ \\
$\quad$ Whole period & $10.97 \pm 0.46$ & $9.99 \pm 0.65$ & $9.89 \pm 0.62$ & $10.75 \pm 0.32$ \\
Body weight gain (BWG) (g) & $1.83 \pm 0.02^{\mathrm{b}}$ & $1.75 \pm 0.01^{\mathrm{b}}$ & $1.78 \pm 0.02^{\mathrm{b}}$ & $2.10 \pm 0.07^{\mathrm{a}}$ \\
$\quad$ Starter phase & $2.62 \pm 0.16^{\mathrm{b}}$ & $2.77 \pm 0.02^{\mathrm{ab}}$ & $2.78 \pm 0.02^{\mathrm{ab}}$ & $2.97 \pm 0.17^{\mathrm{a}}$ \\
$\quad$ Grower phase & $2.22 \pm 0.08^{\mathrm{b}}$ & $2.26 \pm 0.01^{\mathrm{b}}$ & $2.28 \pm 0.02^{\mathrm{b}}$ & $2.54 \pm 0.11^{\mathrm{a}}$ \\
$\quad$ Whole period & & & & \\
Feed conversion ratio (FCR) & $6.35 \pm 0.25^{\mathrm{b}}$ & $6.12 \pm 0.29^{\mathrm{b}}$ & $5.71 \pm 0.39^{\mathrm{ab}}$ & $5.15 \pm 0.16^{\mathrm{a}}$ \\
$\quad$ Starter phase & $3.72 \pm 0.29$ & $2.99 \pm 0.36$ & $3.31 \pm 0.31$ & $3.72 \pm 0.35$ \\
$\quad$ Grower phase & $5.00 \pm 0.33$ & $4.42 \pm 0.29$ & $4.34 \pm 0.27$ & $4.30 \pm 0.24$ \\
$\quad$ Whole period & $7.53 \pm 0.13$ & $7.55 \pm 0.11$ & $7.63 \pm 0.09$ & $7.61 \pm 0.08$ \\
Initial weight (g) & $125.76 \pm 3.81$ & $120.33 \pm 2.83$ & $116.19 \pm 2.99$ & $122.56 \pm 4.28$ \\
Final weight (g) & &
\end{tabular}

Values are expressed in mean \pm standard error ( $n=30$ animals for each four treatment groups). One-way analysis of variance was carried out followed by Duncan's comparison test. ${ }^{\mathrm{a}, \mathrm{b}}$ Different superscripts in the same row indicate significant differences $(p<0.05)$.

Table-4: Effects of experimental diets on meat quality in quail.

\begin{tabular}{lcccc}
\hline \multirow{2}{*}{ Variables } & \multicolumn{4}{c}{ Treatment } \\
\cline { 2 - 5 } & \multicolumn{1}{c}{$\mathbf{C}$} & T1 & T2 & T3 \\
\hline $\mathrm{pH}_{45 \text { min }}$ & $6.19 \pm 0.03$ & $6.17 \pm 0.02$ & $6.19 \pm 0.02$ & $6.19 \pm 0.02$ \\
$\mathrm{pH}_{24 \mathrm{~h}}$ & $6.13 \pm 0.03$ & $6.08 \pm 0.02$ & $6.11 \pm 0.02$ & $6.10 \pm 0.02$ \\
Lightness $_{\text {Redness }}$ & $41.86 \pm 0.09$ & $42.03 \pm 0.13$ & $42.06 \pm 0.12$ & $42.11 \pm 0.21$ \\
Yellowness & $8.08 \pm 0.02^{\mathrm{b}}$ & $8.14 \pm 0.14^{\mathrm{b}}$ & $8.13 \pm 0.01^{\mathrm{b}}$ & $8.46 \pm 0.02^{\mathrm{a}}$ \\
Drip loss (\%) & $12.36 \pm 0.12$ & $12.36 \pm 0.09$ & $12.47 \pm 0.09$ & $12.43 \pm 0.09$ \\
Cooking loss (\%) & $21.54 \pm 0.09^{\mathrm{c}}$ & $20.36 \pm 0.09^{\mathrm{b}}$ & $19.59 \pm 0.16^{\mathrm{a}}$ & $19.39 \pm 0.08^{\mathrm{a}}$ \\
WHC (\%) & $22.65 \pm 0.07^{\mathrm{c}}$ & $21.71 \pm 0.13^{\mathrm{b}}$ & $20.64 \pm 0.16^{\mathrm{a}}$ & $20.37 \pm 0.09^{\mathrm{a}}$ \\
Tenderness (mm/g/10 s) & $66.31 \pm 0.21^{\mathrm{c}}$ & $66.44 \pm 0.24^{\mathrm{c}}$ & $67.26 \pm 0.15^{\mathrm{b}}$ & $68.41 \pm 0.19^{\mathrm{a}}$ \\
\hline
\end{tabular}

Values are expressed in mean \pm standard error $(n=30$ meat samples for each four treatment groups). One-way analysis of variance was carried out followed by Duncan's comparison test. ${ }^{a, b, c}$ Different superscripts in the same row indicate significant differences $(p<0.05)$. 


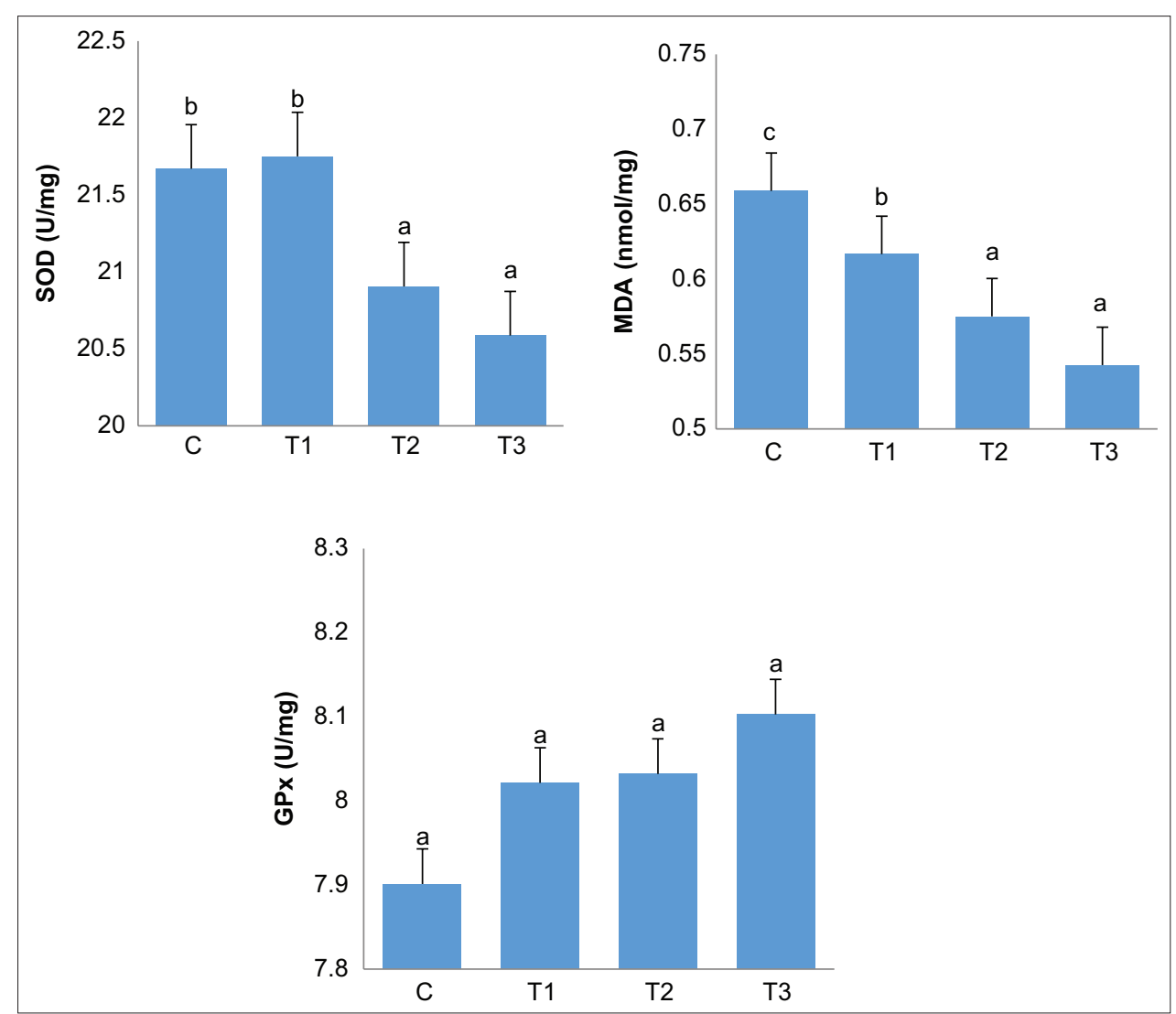

Figure-1: Effects of experimental diets on the antioxidative activities in quail meat. Values are expressed in mean \pm standard error ( $n=30$ meat samples for each four treatment groups). One-way analysis of variance was carried out followed by Duncan's comparison test. $a, b, c$ Different superscripts indicate significant differences $(p<0.05)$. SOD $=$ Superoxide dismutase, MDA=Malondialdehyde, GPx=Glutathione peroxidase.

\section{Discussion}

This study showed the efficacy of breadfruit leaf powder for increasing BWG and FCR, although no significant difference in FI was identified. Breadfruit leaf powder does not have a special taste to increase appetite, which is consistent with the previous studies showing that feeding on a breadfruit leaf powder diet did not increase the palatability of chickens [23]. The fat and crude protein components are proposed to increase the active protoplasm in muscle cells [24]. The proximate analysis in this study revealed fat and crude protein contents of $7.84 \%$ and $18.33 \%$, respectively. A protein level of $16-18 \%$ is ideal to stimulate BWG during the grower phase [25]. Excess protein actually triggers a nitrogen imbalance, which results in high ammonia production [26]. Higher protein diets produce an increase in heat, which occurs due to $\mathrm{N}$ degradation resulting in the catabolism of amino acids into uric acid [27]. The limited capacity of the intestine to absorb amino acids can increase the excretion of amino acids in the urine [28].

The levels of calcium and metabolic energy available in feed are believed to accelerate growth and be efficient at improving FCR [29]. Calcium levels can maintain the development of muscle mass and stabilize actin and myosin activity during muscle contraction [30]. A lack of calcium in feed can increase the likelihood of hypocalcemia and paralysis in the extremities [31]. To maintain the growth phase, there is a need for metabolic energy in standard feed of at least $2880 \mathrm{kcal} / \mathrm{kg}$ [32]. Regarding the experimental diet in this study, it was shown to have a metabolic energy content consistent with minimum standards of $2880 \mathrm{kcal} / \mathrm{kg}$. Metabolic energy can increase the FCR value and is positively correlated with BWG [33]. An increase in the FCR value was also revealed at the starter phase in this study.

In terms of meat quality, this study also reported on variables such as $\mathrm{pH}$, color, freshness, and meat tenderness, which are crucial criteria for consumer satisfaction [34]. The $\mathrm{pH}$ of the meat of quail fed with breadfruit leaf powder showed no significant difference from that of the control group. Meat with $\mathrm{pH}$ of $<5.7$ is categorized as pale, soft, and exudative (PSE). Meanwhile, meat with a $\mathrm{pH}$ of $>6.1$ is categorized as dark, firm, and dry (DFD) [35]. The pH is also influenced by muscle glycogen catabolism by anaerobic glycolysis enzymes and lactic acid accumulation [36]. High lactic acid in meat results in a decrease in the postmortem $\mathrm{pH}$. In addition, increased levels of lactic acid are supported by postmortem glycolysis activity by pyruvate kinase and lactate dehydrogenase $[37,38]$.

Meat color is one of the most important quality criteria related to $\mathrm{pH}, \mathrm{WHC}$, and meat shear force [39]. Meat with a lightness value of $>53$ is categorized as PSE meat. The lightness of meat is considered to be normal 
when the score is $48-53$. On the other hand, meat with a score of $<46$ is categorized as DFD meat [40]. PSE meat is influenced by protein denaturation in muscle and postmortem $\mathrm{pH}$ [37]. The present study reported that supplementation with breadfruit leaf powder had a significant effect on the redness of quail meat. Lightness and redness values are more idiosyncratic reflecting than yellowness values in poultry meat [41]. The redness value of meat depends on the redox reactions of myoglobin, hemoglobin, and heme pigment [42]. Meanwhile, yellowness in poultry is influenced by factors such as genetics, carotenoid pigments in feed, liver biochemistry, and meat processing [43].

In this study, the treatment groups differed significantly from the control group in terms of the variables of drip loss, cooking loss, WHC, and tenderness. Drip loss has the potential to occur at $24 \mathrm{~h}$ postmortem [44]. In general, drip loss is a process that involves the transfer of water from myofibrils in muscle tissue to extracellular tissue [45]. The level of drip loss is related to the functions of actin and myo$\sin$ in the muscle after slaughter [46]. Quail that consumed the experimental diet had protoplasm reserves in muscle cells, which reduced protein denaturation. The availability of protoplasm increases the ability to bind water and prevents the release of water from meat [47]. Alleviation of the denaturation of myofibrillar and sarcoplasmic proteins can maintain muscle physiology [48], increase the ability of proteins to bind water, produce optimal WHC [49], and prevent the loss of soluble sarcoplasmic constituents from muscle cells to extracellular tissue [50]. The optimal percentage of WHC is supported by membrane integrity due to improvement in the level of creatine kinase and an increase in the hematocrit [51]. Here, there was a finding consistent with the previous studies that creatine kinase activity decreased with decreasing percentage of drip loss in broiler chickens [52].

Meat quality is also associated with oxidant and feed scavenger properties in different ways [53]. The antioxidant properties of breadfruit leaf powder are conferred through components such as phenolics and flavonoids [54], which react with lipid and hydroxyl radicals, and then convert them into resistant compounds [55]. Flavonoids can activate lipase, which plays a role in converting intramuscular fat into fatty acids and glycerol [56]. At lipolysis mechanism, which is initiated by lipase activity, this will then be followed by an increase in meat tenderness. Meat tenderness also depends on collagens. Meat tenderness has been reported to increase with decreasing intramuscular fat and collagen levels [57]. In addition, meat tenderness was shown to be related to myofibril protein, myofibril integrity, and rigor status [58].

In this study, regarding the antioxidant activity, there were improvements in SOD and MDA levels in the T3 group. On the other hand, GPx levels showed similar results in all treatment groups. Phenolic compounds inhibit lipid peroxidation, particularly unsaturated fatty acids [59], which leads to the antioxidant properties of the experimental feed [60]. Dietary supplements have been reported to modulate endogenous antioxidants and cell barriers [61]. In the previous studies, breadfruit leaf powder containing phenolics was reported to reduce antioxidant activity in layer [62] and broiler chickens [63]. The SOD enzyme prevents free hydroxyls by producing hydrogen peroxide and oxygen [64]. The low levels of endogenous SOD and MDA in quail meat suggest the potential of phenolics of breadfruit leaf powder as scavengers to reduce antioxidant activity. Moreover, the antioxidant activity decreased with improving quality of quail meat, emphasizing the findings of this study regarding the efficacy of breadfruit leaf powder.

\section{Conclusion}

Dietary supplementation with breadfruit leaf powder was shown to improve growth performance, meat quality, and antioxidant activity in Japanese quail. Supplementation of the basal diet with $10 \mathrm{~g} / \mathrm{kg}$ breadfruit leaf powder positively influenced meat color, drip loss, cooking loss, WHC, and meat tenderness. Although there were no significant differences in the levels of GPx, the improvements of SOD and MDA also indicated the efficacy of breadfruit leaf powder, perhaps due to its antioxidant compounds. These findings suggest the potential of breadfruit leaf powder as an alternative feed for improving the productivity and quality of quail meat.

\section{Authors' Contributions}

MTEP: Supervised the study. EPE, FF, and AP: Conducted the study. SK: Helped in the statistical analysis of the data. AP and SK: Helped in the visualization of tables and figures. AP and SC: Drafted the manuscript. MTEP and SC: Revised and submitted the manuscript. All authors read and approved the final manuscript.

\section{Acknowledgments}

We thank Mr. Kayitono for providing the DOQ from his breeding farm. This study was supported by grants from the Faculty of Veterinary Medicine, Universitas Airlangga, Indonesia, and PSDKU Banyuwangi Universitas Airlangga, Indonesia with grant number 1815/UN3/2019.

\section{Competing Interests}

The authors declare that they have no competing interests.

\section{Publisher's Note}

Veterinary World remains neutral with regard to jurisdictional claims in published institutional affiliation.

\section{References}

1. Wahyono, N.D. and Utami, M.M.D. (2018) A review of the poultry meat production industry for food safety in 
Indonesia. Int. J. Phys. Conf. Ser., 953(1): 012125.

2. Santhi, D. and Kalaikannan, A. (2017) Japanese quail (Coturnix coturnix japonica) meat: Characteristics and value addition. Worlds Poult. Sci. J., 73(2): 337-344.

3. Vargas-Sánchez, R.D., Ibarra-Arias, F.J., del Mar TorresMartínez, B., Sánchez-Escalante, A. and TorrescanoUrrutia, G.R. (2019) Use of natural ingredients in the Japanese quail diet and their effect on carcass and meat quality. Review. Asian-Australas J. Anim. Sci., 32(11): 1641-1656.

4. Nadal, J., Ponz, C. and Margalida, A. (2018) Synchronizing biological cycles as key to survival under a scenario of global change: The Common quail (Coturnix coturnix) strategy. Sci. Total Environ., 613(2): 1295-1301.

5. Vali, N., Edriss, M.A. and Rahmani, H.R. (2005) Genetic parameters of body and some carcass traits in two quail strains. Int. J. Poult. Sci., 4(5): 296-300.

6. Chowdhury, E.U. and Morey, A. (2019) Intelligent packaging for poultry industry. J. Appl. Poult. Res., 28(4): 791-800.

7. Bekhit, A.E.D., Carne, A., Ha, M. and Franks, P. (2014) Physical interventions to manipulate texture and tenderness of fresh meat: A review. Int. J. Food Prop., 17(2): 433-453.

8. Hocquette, J.F., Gondret, F., Baéza, E., Médale, F., Jurie, C. and Pethick, D.W. (2010) Intramuscular fat content in meat-producing animals: Development, genetic and nutritional control, and identification of putative markers. Animal, 4(2): 303-319.

9. Medyński, A., Pospiech, E. and Kniat, R. (2000) Effect of various concentrations of lactic acid and sodium chloride on selected physico-chemical meat traits. Meat Sci., 55(3): 285-290.

10. Okuskhanova, E., Rebezov, M., Yessimbekov, Z., Suychinov, A., Semenova, N., Rebezov, Y., Gorelik, O. and Zinina, O. (2017) Study of water binding capacity, $\mathrm{pH}$, chemical composition and microstructure of livestock meat and poultry. Annu. Res. Rev. Biol., 14(3): 1-7.

11. Narinc, D., Aksoy, T., Karaman, E., Aygun, A., Firat, M.Z. and Uslu, M.K. (2013) Japanese quail meat quality: Characteristics, heritabilities, and genetic correlations with some slaughter traits. Poult. Sci., 92(7): 1735-1744.

12. Amusa, N.A., Kehinde, I.A. and Ashaye, O.A. (2002) Bio-deterioration of breadfruit (Artocarpus communis) in storage and its effects on the nutrient composition. Afr. $J$. Biotechnol., 1(2): 57-60.

13. Tavárez, M.A., Boler, D.D., Bess, K.N., Zhao, J., Yan, F., Dilger, A.C., McKeith, F. K. and Killefer, J. (2011) Effect of antioxidant inclusion and oil quality on broiler performance, meat quality, and lipid oxidation. Poult. Sci., 90(4): 922-930.

14. Leyva, C.S., Valdivié, M. and Ortiz, A. (2012) Utilization of fruit and leaf meals from breadfruit tree (Artocarpus altilis) for fattening New Zealand White rabbits. Pastos Forrajes, 35(4): 443-452.

15. AOAC. (2012) AOAC Official Methods of Analysis. $18^{\text {th }}$ ed. AOAC International, Gaithersburg, USA.

16. Alnahhas, N., Berri, C., Chabault, M., Chartrin, P., Boulay, M., Bourin, M.C. and Le Bihan-Duval, E. (2016) Genetic parameters of white striping in relation to body weight, carcass composition, and meat quality traits in two broiler lines divergently selected for the ultimate $\mathrm{pH}$ of the pectoralis major muscle. BMC Genet., 17(1): 1-9.

17. Salueña, B.H., Gamasa, C.S., Rubial, J.M.D. and Odriozola, C.A. (2019) CIELAB color paths during meat shelf life. Meat Sci., 157(11): 107889.

18. Logan, B.G., Bush, R.D., Biffin, T.E., Hopkins, D.L. and Smith, M.A. (2019) Measurement of drip loss in alpaca (Vicugna pacos) meat using different techniques and sample weights. Meat Sci., 151(5): 1-3.

19. Purslow, P.P., Oiseth, S., Hughes, J. and Warner, R.D. (2016) The structural basis of cooking loss in beef: Variations with temperature and ageing. Food Res. Int., 89(11): 739-748.

20. Zhang, Z., Yang, Y., Tang, X., Chen, Y. and You, Y. (2015) Chemical forces and water holding capacity study of heat-induced myofibrillar protein gel as affected by high pressure. Food Chem., 188(12): 111-118.

21. Lengkey, H.A.W., Siwi, J.A., Edianingsih, P. and Nangoy, F.J. (2013) The effect of transportation on broiler meat $\mathrm{pH}$ and tenderness. Biotechnol. Anim. Husbandry, 29(2): 331-336.

22. Purnama, M.T.E., Dewi, W.K., Prayoga, S.F., Triana, N.M., Aji, B.S.P., Fikri, F. and Hamid, I.S. (2019) Preslaughter stress in banyuwangi cattle during transport. Indian Vet. J., 96(12): 50-52.

23. Lestari, S., Telebe, Y.B. and Sapsuha, Y. (2020) The Effect of Giving Breadfruit Leaf Flour (Artocarpus Altilis) on the Productivity of Laying Hens. In: $5^{\text {th }}$ International Conference on Food, Agriculture and Natural Resources (FANRes 2019). Atlantis Press, Berlin, Germany. p414-418.

24. Atti, N., Rouissi, H. and Mahouachi, M. (2004) The effect of dietary crude protein level on growth, carcass and meat composition of male goat kids in Tunisia. Small Rumin. Res., 54(2): 89-97.

25. Ratriyanto, A., Indreswari, R. and Nuhriawangsa, A.M.P. (2017) Effects of dietary protein level and betaine supplementation on nutrient digestibility and performance of Japanese quails. Braz. J. Poult. Sci., 19(3): 445-454.

26. Chen, D., Wang, S., Xiong, B., Cao, B. and Deng, X. (2015) Carbon/nitrogen imbalance associated with drought-induced leaf senescence in Sorghum bicolor. PLoS One, 10(8): e0137026.

27. Lee, K.P. (2007) The interactive effects of protein quality and macronutrient imbalance on nutrient balancing in an insect herbivore. J. Exp. Biol., 210(18): 3236-3244.

28. Lemme, A., Ravindran, V. and Bryden, W.L. (2004) Ileal digestibility of amino acids in feed ingredients for broilers. Worlds Poult. Sci. J., 60(4): 423-438.

29. Ankra-Badu, G.A., Pesti, G.M. and Aggrey, S.E. (2010) Genetic interrelationships among phosphorus, nitrogen, calcium, and energy bioavailability in a growing chicken population. Poult. Sci., 89(11): 2351-2355.

30. Wakabayashi, T. (2015) Mechanism of the calcium-regulation of muscle contraction-in pursuit of its structural basis. Proc. Jpn. Acad. Ser. B, 91(7): 321-350.

31. Schenck, P.A., Chew, D.J., Nagode, L.A. and Rosol, T.J. (2006) Disorders of calcium: Hypercalcemia and hypocalcemia. Fluid Electrolyte Acid Base Disord. Small Anim. Pract., 4(3): 120-194.

32. Chen, X., Wilfart, A., Puillet, L. and Aubin, J. (2017) A new method of biophysical allocation in LCA of livestock co-products: Modeling metabolic energy requirements of body-tissue growth. Int. J. Life Cycle Assess., 22(6): 883-895.

33. Zhao, P.Y. and Kim, I.H. (2017) Effect of diets with different energy and lysophospholipids levels on performance, nutrient metabolism, and body composition in broilers. Poult. Sci., 96(5): 1341-1347.

34. Xazela, N.M., Hugo, A., Marume, U. and Muchenje, V. (2017) Perceptions of rural consumers on the aspects of meat quality and health implications associated with meat consumption. Sustainability, 9(5): 830.

35. Poznyakovskiy, V.M., Gorlov, I.F., Tikhonov, S.L. and Shelepov, V.G. (2015) About the quality of meat with PSE and DFD properties. Foods Raw Mater., 3(1): 104-110.

36. Sawyer, J.T., Apple, J.K. and Johnson, Z.B. (2008) The impact of lactic acid concentration and sodium chloride on $\mathrm{pH}$, water-holding capacity, and cooked color of injection-enhanced dark-cutting beef. Meat Sci., 79(2): 317-325.

37. Donaldson, A.E. and Lamont, I.L. (2013) Biochemistry changes that occur after death: Potential markers for determining post-mortem interval. PLoS One, 8(11): e82011.

38. Scheier, R. and Schmidt, H. (2013) Measurement of the $\mathrm{pH}$ value in pork meat early postmortem by Raman spectroscopy. Appl. Phys. B, 111(2): 289-297.

39. Le Bihan-Duval, E., Debut, M., Berri, C.M., Sellier, N., Santé-Lhoutellier, V., Jégo, Y. and Beaumont, C. (2008) Chicken meat quality: Genetic variability and relationship 
with growth and muscle characteristics. BMC Genet., 9(1): $1-6$.

40. Öztürk, B. and Serdaroğlu, M. (2015) Quality characteristics of PSE-like turkey Pectoralis major muscles generated by high post-mortem temperature in a local Turkish slaughterhouse. Korean J. Food Sci. Anim. Resour., 35(4): 524.

41. Tang, S., Yu, J., Zhang, M. and Bao, E. (2013) Effects of different heat stress periods on various blood and meat quality parameters in young Arbor Acer broiler chickens. Can. J. Anim. Sci., 93(4): 453-460.

42. Calnan, H., Jacob, R.H., Pethick, D.W. and Gardner, G.E. (2016) Production factors influence fresh lamb longissimus colour more than muscle traits such as myoglobin concentration and pH. Meat Sci., 119(11): 41-50.

43. King, N.J. and Whyte, R. (2006) Does it look cooked? A review of factors that influence cooked meat color. J. Food Sci., 71(4): R31-R40.

44. Yu, L.H., Lee, E.S., Jeong, J.Y., Choi, J.H. and Kim, C.J. (2009) Effects of post-mortem temperature on the physicochemical properties of hot-boned chicken breast muscles. Food Sci. Anim. Resour., 29(1): 55-61.

45. Holman, B.W., Alvarenga, T.I. and Hopkins, D.L. (2020) The effect of fibre orientation, measurement interval and muscle on lamb meat drip loss values. Meat Sci., 161(3): 107959.

46. Traore, S., Aubry, L., Gatellier, P., Przybylski, W., Jaworska, D., Kajak-Siemaszko, K. and SantéLhoutellier, V. (2012) Higher drip loss is associated with protein oxidation. Meat Sci., 90(4): 917-924.

47. Stefanovskiy, V. (2019) Processes and technological systems for thawing of fish. In: Novel Technologies and Systems for Food Preservation, IGI Global. p51-77.

48. Choi, Y.M. and Kim, B.C. (2009) Muscle fiber characteristics, myofibrillar protein isoforms, and meat quality. Livest. Sci., 122(3): 105-118.

49. Huff-Lonergan, E. and Lonergan, S.M. (2005) Mechanisms of water-holding capacity of meat: The role of postmortem biochemical and structural changes. Meat Sci., 71(1): 194-204.

50. Liu, J., Arner, A., Puolanne, E. and Ertbjerg, P. (2016) On the water-holding of myofibrils: Effect of sarcoplasmic protein denaturation. Meat Sci., 119(11): 32-40.

51. Nkukwana, T.T., Muchenje, V., Masika, P.J., Pieterse, E., Hoffman, L.C. and Dzama, K. (2016) Proximate composition and variation in colour, drip loss and $\mathrm{pH}$ of breast meat from broilers supplemented with Moringa oleifera leaf meal over time. Anim. Prod. Sci., 56(7): 1208-1216.

52. Brossi, C., Montes-Villanueva, N., Rios-Mera, J.D.,
Delgado, E.F., Menten, J.M. and Contreras-Castillo, C.J. (2018) Acute heat stress detrimental effects transpose high mortality rate and affecting broiler breast meat quality. Sci. Agropecu., 9(3): 305-311.

53. Guo, Z.Y., Li, J.L., Zhang, L., Jiang, Y., Gao, F. and Zhou, G.H. (2014) Effects of alpha-lipoic acid supplementation in different stages on growth performance, antioxidant capacity and meat quality in broiler chickens. $B r$. Poult. Sci., 55(5): 635-643.

54. Adebowale, K.O., Olu-Owolabi, B.I., Olawumi, E.K. and Lawal, O.S. (2005) Functional properties of native, physically and chemically modified breadfruit (Artocarpus artilis) starch. Ind. Crops Prod., 21(3): 343-351.

55. Ciftci, M., Simsek, U.G., Yuce, A., Yilmaz, O. and Dalkilic, B. (2010) Effects of dietary antibiotic and cinnamon oil supplementation on antioxidant enzyme activities, cholesterol levels and fatty acid compositions of serum and meat in broiler chickens. Acta Vet. Brno, 79(1): 33-40.

56. Chebil, L., Humeau, C., Falcimaigne, A., Engasser, J.M. and Ghoul, M. (2006) Enzymatic acylation of flavonoids. Proc. Biochem., 41(11): 2237-2251.

57. Lepetit, J. (2007) A theoretical approach of the relationships between collagen content, collagen cross-links and meat tenderness. Meat Sci., 76(1): 147-159.

58. Marino, R., Albenzio, M., Malva, A.D., Santillo, A., Loizzo, P. and Sevi, A. (2013) Proteolytic pattern of myofibrillar protein and meat tenderness as affected by breed and aging time. Meat Sci., 95(2): 281-287.

59. Khennouf, S., Amira, S., Arrar, L. and Baghiani, A. (2010) Effect of some phenolic compounds and quercus tannins on lipid peroxidation. World Appl. Sci. J., 8(9): 1144-1149.

60. Leng, L.Y., Nadzri, N.B., Yee, K.C. and Shaari, A.R. (2018) Antioxidant and total phenolic content of breadfruit (Artocarpus altilis) leaves. MATEC Web Con., 150(4): 06007.

61. Grimble, R.F. (2001) Nutritional modulation of immune function. Proc. Nutr. Soc., 60(3): 389-397.

62. Ogbuewu, I.P. and Mbajiorgu, C.A. (2019) Potential of leaf and seeds of tropical plants in chicken diets: Effect on spermatozoa and egg production. Trop. Anim. Health Prod., 51(2): 267-277.

63. Hasibuan, A.S., Silalahi, J. and Masfria, M. (2019) The effect of herbal extracts and probiotic feeding on productivity and quality of broilers. Asian J. Pharm. Res. Dev., 7(3): 5-9.

64. Afonso, V., Champy, R., Mitrovic, D., Collin, P. and Lomri, A. (2007) Reactive oxygen species and superoxide dismutases: Role in joint diseases. Joint Bone Spine, 74(4): 324-329. 